\title{
Dinamika Lembaga Pendidikan Dasar Dalam Pengelolaan Pembelajaran Daring
}

\author{
Ramdanil Mubarok \\ STAI Sangat Kutai Timur \\ e-mail: danil.education@gmail.com
}

\begin{abstract}
This paper aims to look at the basic concepts of primary education during a pandemic, understand the courageous concept of learning during a pandemic, and see whenever the primary school manages the learning during a pandemic. The result is that primary education institutions are the institutions from which a child's formal education begins. This bold model of learning allows educators and students to learn without having to meet. The dynamics of primary education institutions in the management of bold learning, namely by compiling bold learning plans, conducting mapping in learning, implementing bold learning according to plans to achieve goals, and conducting indicator evaluations, evaluations, environmental evaluations. Conduct evaluations such as process indicators, activities, maintenance, and solutions. Evaluating the teaching staff, evaluating students, and evaluating the facilities.
\end{abstract}

Keywords: educational institutions, management, online learning

\begin{abstract}
Abstrak
Tulisan ini bertujuan untuk mengetahui konsep lembaga pendidikan dasar di masa Pandemi, mengetahui konsep pembelajaran daring di masa pandemi dan mengetahui dinamika lembaga pendidikan dasar dalam pengelolaan pembelajaran daring di masa pandemi. Hasilnya adalah bahwa lembaga pendidikan dasar merupakan lembaga yang menjadi awal mula pendidikan formal seorang anak. Pembelajaran model daring ini memungkinkan pendidik dan peserta didik melakukan pembelajaran tanpa harus bertemu. Dinamika lembaga pendidikan dasar dalam pengelolaan pembelajaran daring yaitu dengan menyusun rencana pembelajaran daring, melakukan pemetaan dalam pembelajaran daring, melaksanakan pembelajaran daring sesuai rencana untuk mencapai tujuan, dan melakukan evaluasi yang meliputi evaluasi indikator, evaluasi kebutuhan, evaluasi lingkungan. Melakukan evaluasi proses seperti indikator proses, aktivitas, kendala, dan solusi. Melakukan evaluasi terhadap tenaga pendidiknya, evaluasi peserta didiknya, dan evaluasi keadaan sarana dan prasarananya.
\end{abstract}

Kata Kunci : lembaga pendidikan, pengelolaan, pembelajaran daring

\section{INTRODUCTION}

Sebuah lembaga pendidikan dasar lahir dalam situasi berkumpulnya seseorang yang ahli dibidang masing-masing kemudian dari perkumpulan tersebut terbentuklah sebuah lembaga pendidikan yang akan menghasilkan suatu yang bermanfaat dimasa yang akan datang. Setiap lembaga pendidikan dasar pada hakikatnya menginginkan sesuatu yang lebih baik. Kemauan sebuah lembaga pendidikan dasar untuk lebih baik seharusnya didukung 
dan disosialisaikan apa yang menjadi program unggulannya.

Lembaga pendidikan dasar akan bersaing menjadi lebih baik apabila dikelola dengan manajemen yang baik pula. Pada hakikatnya persaingan untuk menjadi lebih baik dalam hidup ini akan selalu ada dan seharusnya dibarengi dengan kompetensi yang mumpuni. Seorang guru akan bersaing lebih baik dari guru yang lain, seorang murid akan bersaing menjadi yang terbaik di kelasnya, begitu juga lembaga pendidikan akan bersaing dengan lembaga pendidikan yang lain. Dalam kondisi seperti saat ini dimana pandemi covid menjadi momok yang sangat menyulitkan bagi dunia pada umumnya dan dunia pendidikan pada khususnya.

Pemerintah mendeklarasikan pandemi Covid-19 sebagaiman yang diistilahkan oleh WHO yaitu PHEIC (Public Health Emergency Of Internasional Concern) (Pandoman, 2020). Di Indonesia sendiri masuknya covid19 berawal dari bulan maret tahun 2020 yang mana sejak itu semua pekerjaan dan aktifitas pembelajaran dipusatkan di rumah. Dengan diberlakukannya bekerja dari rumah dan sekolah dari rumah sedikit tidak akan dapat mempengaruhi lembaga pendidikan.

Lembaga pendidikan yang berhasil mengatasi keunikan lingkungan akan mampu memanfaatkan sumber daya dalam menghadapi berbagai masalah untuk menjaga pertumbuhan dan fleksibilitas namun permasalahan utamanya adalah adanya pandemi Covid-19. Ini menjadi penting untuk dikaji tentang dinamikanya dalam mempertahankan eksistensinya sehingga terhindar dari kemunduran yang disebabkan oleh pandemi Covid-19 ini. Secara keseluruhan, untuk menjaga eksistensi lembaga pendidikan diperlukan langkah pengembangan yang kongkrit. Pengembangan kelembagaan meliputi penataan kembali struktur kelembagaan dan melibatkan semua faktor yang mempengaruhi tanggung jawab dan fungsi seluruh lembaga. Faktor yang mempengaruhi perubahan sistem atau desain sistem maupun faktor lingkungan eksternal dan internal sistem.

Kehidupan lembaga pendidikan memerlukan strategi yang sinergis dengan tujuan, kebijakan kelembagaan, dan kebijakan pemerintah lembaga tersebut, dan serangkaian tindakan dilakukan dalam suatu pernyataan yang saling mengikat. Strategi organisasi biasanya terkait dengan prinsip umum untuk menyelesaikan tugas yang diprakarsai oleh organisasi, dan bagaimana organisasi memilih cara tertentu untuk mencapai tugas tersebut. Strategi mencerminkan kesadaran organisasi tentang bagaimana, kapan dan di mana bersaing dengan pesaing dan untuk tujuan apa.

Penelitian terdahulu yang relevan antara lain yang dilakukan oleh (Efferi, 2015) menyimpulakan bahwa diperlukan strategi dalam memenangkan kompetensi lembaga pensisikan serta meningkatkan akselerasi peningkatan kualitas dan profesionalisme menejemen lembaga pendidikan. Selanjutnya hasil penelitiannya yang mengatakan bahwa pengembangan sistem pengelolaan pembelajaran daring untuk sekolah menengah membutuhkan pembelajaran daring yang optimal diluar kelas karena e-learning tidak membatasi pembelajaran dimanapun guru dan siswa berada (Lakoriha, Wowor, Elektro, Sam, \& Manado, 2018). Begitu juga penelitian (Rahman, 2018) mengatakan bahwa sistem pendidikan lembaga pesantren awalanya cenderung tradisional baik dari segi metode maupun sarpras. Dalam (Surur \& Nadhirin, 2020) bahwa terdapat perubahan dalam kehidupan lembaga pendidikan sejak adanya pandemi covid-19 terutama dalam proses belajar mengajar yang semula dilakukan dengan tatap muka kini beralih ke virtual.

Ditengah wabah pandemi covid-19 ini dengan segala kontroversinya lalu bagaimana dinamika lembaga pendidikan dasar dalam pengelolaan pembelajaran daring di masa pandemi? Tulisan ini bertujuan untuk mengetahui konsep lembaga pendidikan dasar di masa pandemi, mengetahui konsep pembelajaran daring di masa pandemi dan mengetahui dinamika lembaga pendidikan dasar dalam pengelolaan pembelajaran daring di masa pandemi.

\section{METHODS}

Penelitian ini menggunakan kajian literatur dengan membaca jurnal, artikel, buku referensi yang relevan dengan judul. Penelitiann ini merupakan penenlitan kualitatif yang akan digunakan untuk mencari konsep 
lembaga pendidikan dasar, pembelajaran daring, serta pencapaian pengelolaan pembelajaran daring di lembaga pedidikan dasar. Penelitian kualitatif ini bertujuan untuk memperoleh gambaran data seutuhnya megenai hal yang diteliti. Penelitian kualitatif juga merupakan penelitian yang berhubungan dengan presefsi, ide, pendapat atau bahkan kepercayaan, yang mana kesemua hal tersebut tidak akan dapat diukur dengan angka-angka. Penelitian kualitatif melibatkan studi menggunakan dan mengoreksi variasi materimateri empiris, studi kasus, pengalaman personal, introspektif, life histori, interview, observasi, sejarah, interaksional, dan teks visual yang menggambarkan rutinitas dan problem waktu (Gunawan, 2013).

Salah satu pendekatan dalam penelitian kualitatif adalah pendekatan kepustakaan (Library research). Penelitian Library research atau Literatue review yang kalau diterjemahkan dengan istilah tinjauan pustaka adalah bahan yang tertulis berupa buku, jurnal yang membahas tentang topik yang hendak diteliti. Tinjauan pustaka membantu peneliti untuk melihat ide-ide, pendapat, dan kritik tentang topik tersebut yang sebelumnya dibangun dan dianalisis oleh para ilmuan sebelumnya. Pendapat (Raco, 2018) bahwa Pentingnya tinjauan pustaka untuk melihat dan menganalisa nilai tambah penelitian ini dibandingkan dengan penelitian sebelumnya

Sementara mengutip dari Syaodih mengatakan bahwa metode penelitian menggunakan studi kepustakaan (library research) dengan menghimpun data dari tulisan-tulisan (literasi) yang mempunyai kaitan dengan topik yang dibahas. Data-data tersebut peneliti ambil dari dokumentasi yang bentuk, buku, makalah, jurnal, dan artikel, metode pembahasan menggunakan metode deskriptif-analisis, yaitu menjelaskan serta mengelaborasi ide- ide utama yang berkenaan dengan topik yang dibahas. Kemudian menyajikannya secara kritis melalui sumbersumber pustaka primer maupun skunder yang berkaitan dengan tema ini (Priyatno, 2020).

Peneliti mengumpulkan tulisan-tulisan yang ada kaitannya dengan lembaga pendidikan dan pembelajaran daring. Untuk mendapatkan data-data penelitian tersebut maka peneliti harus membaca buku, makalah, jurnal, artikel, koran, dan majalah. Analisis data penelitian ini menggunakan metode induktif berdasarkan fakta yang ada. Metode berfikir induktif adalah metode berfikir dimana kesimpulan diperoleh dari hasil induksi sehnigga dapat ditarik kesimpulan (Harahap \& Hamidah, 2019). Pembahasan menggunakan metode deskripsi analisis untuk menguraikan serta menyatukan ide-ide yang berkaitan dengan dinamika lembaga pendidikan dalam pengelolaan pembelajaran daring. Setelah semuanya terkumpul maka selanjutkan dikaji secara kritis dengan menggunakan data-data diatas baik berupa data primer maupun skunder.

\section{FINDING AND DISCUSSIONS}

\section{Lembaga Pendidikan Dasar}

Lembaga pendidikan merupakan salah satu pusat pendidikan yang menitik beratkan pada pendidikan formal yang memiliki prosedur pedidikan yang telah diatur sedemikian rupa mulai dari kurikulumnya, gurunya, siswanya, jadwal pelajarannya, serta sarana dan prasarananya (Syarif, 2015). Lembaga pendidikan dasar merupakan sebuah lembaga pendidikan yang mewadahi pembelajaran ditingkat anak-anak. Rentan umur anak di lembaga pendidikan dasar antara tujuh tahun sampai dengan tigabelas tahun. Pada tingkat pendidikan dasar merupakan level pendidikan untuk menggali pertumbuhan minat, mengasah kemampuan berpikir serta mengolah tubuh dan naluri seorang anak. Hal tersebut sesuai dengan pengertiang pendidikan dasar yang digagas dalam UUD 50 tentang definisi pendidikan dasar.

Lembaga pendidikan dasar merupakan wujud pendidikan yang melandasi jenjang pendidikan seanjutnya. Pendidikan dasar ada dua macam yaitu sekolah dasar dan madrasah ibtidaiyah. Kedua istilah lembaga pendidikan dasar tersebut memang berbeda dari segi penamaan namun pada hakikatnya sama-sama masuk dalam kategori pendidikan dasar. Yang menjadi perbedaan mendasar antara keduanya adalah bahwa sekolah dasar lebih kepada sistem pembelajaran yang umum jika ditelusuri dari segi kurikulum. Sebaliknya untuk Madrasah Ibtidaiyah merupakan lembaga pendidikan madrasah ditingkat dasar yang 
lebih condong kepada pendidikan agama Islam. Kompleksitas lembaga pendidikan tidak hanya terjadi pada proses modernisasi namun model-model kelembagaan dan substansi pembelajaran yang akan menjadi respon terhadap modernisasi tersebut (Subhan, 2012)

UU RI No. 20 tahun 2003 pada pasal 17 menerangkan bahwa 1) pendidikan dasar merupakan jenjang pendidikan yang melandasi jenjang pendidikan menengah, 2) pendidikan dasar berbentuk sekolah dasar (SD) dan madrasah ibtidaiyah (MI) atau dalam bentuk lain yang sederajat serta sekolah menengah pertama (SMP) dan Madrasah tsanawiyah (MTs.), atau bentuk lain yang sederajat, 3) Ketentuan mengenai pendidikan dasar sebagaimana dimaksud pada ayat (1) dan (2) diatur lebih lanjut dengan pemerintahan (Presiden, 2003). Demikian juga dengan UU No. 2 tahun 1989, pendidikan dasar diselenggarakan untuk mengembangkan sikap dan kemampuan serta memberikan pengetahuan dan keterampilan dasar yang diiperlukan untuk hidup dalam masyarakat serta mempersiapkan peserta didik yang memenuhi persyaratan untuk mengikuti pendidikan menengah.

Dalam proses pencapaian tujuan, lembaga perlu berkembang agar proses tersebut dapat dilaksanakan dengan efisien. Dalam artian bahwa pengembangan kelembagaan merupakan upaya yang berkesinambungan dan bersedia melakukan perubahan secara berkelanjutan. Jika demikian maka pengembangan kelembagaan merupakan upaya jangka panjang, bukan upaya jangka pendek. Sebagai hasil dari perkembangan dan persaingan, perkembangan organisasi bisa menjadi positif atau negatif.

Perkembangan positif memberikan kekuatan bagi organisasi untuk beradaptasi dengan lingkungan. Karena sifat alami dan manajemen yang buruk, pembangunan berada pada arah yang tidak menguntungkan, yang menyebabkan kemunduran atau bahkan keruntuhan organisasi. Pada saat yang sama, melalui analisis dan desain yang cermat, pengembangan pengembangan akan membawa lebih banyak peluang ke arah positif dari pengembangan, persaingan, dan kelangsungan hidup organisasi yang berkelanjutan.
Perubahan lingkungan yang begitu cepat tidak dapat lagi diatasi melalui proses pengembangan kelembagaan yang "bergerak" secara alami. Pengembangan dan perancangan diperlukan untuk mengimplementasikan perubahan yang direncanakan agar organisasi dapat bergerak ke arah yang positif dan dapat menghadapi lingkungannya. Arah dan kecepatan pengembangan sistem sangat bergantung pada desain pengembangan sistem dan keberhasilan proses transformasinya. Untuk ini, dibutuhkan orang-orang dengan pengetahuan profesional untuk merancang pengembangan kelembagaan di masa pandemi covid-19. Keterlambatan dalam memutuskan dalam melakukan suatu perubahan dan pengembangan merupakan faktor utama dari perkembangan sistem, yang menyebabkan pertumbuhan sistem yang stagnan. Hal ini terjadi karena pengelola organisasi tidak dapat menggali dan mendiagnosis masalah internal dan eksternal organisasi, sehingga tidak dapat mengidentifikasi dan menganalisis dengan tepat alasan yang ada sebagai dasar bagi perkembangan dan pertumbuhan organisasi.

Penting untuk mempelajari secara mendalam alasan pengembangan organisasi untuk membuat keputusan secara tepat waktu, langkah demi langkah dan tindakan. Alasan pengembangan sistem juga bisa negatif atau positif Alasan negatif tidak didasarkan pada analisis, kebutuhan dan alasan irasional, sedangkan alasan positif didasarkan pada data, analisis, penelitian dan pada dasarnya rasional.

\section{Pembelajaran Daring}

Pembelajaran daring dikenal dikalangan Masyarakat dan akademik dengan istilah pembelajaran online (online learning).(Pohan, 2020) Istilah lain yang sangat umum diketahui adalah pembelajaran jarak jauh (learning distance) (Pratama \& Mulyati, 2020). Pembelajaran daring merupakan pembelajaran yang berlangsung di dalam jaringan dengan bertatap muka melalui virtual. Menurut (Isman, 2016) pembelajaran daring merupakan pembelajaran yang memanfaatkan jaringan internet dalam proses pembelajaran. Sedangkan menurut (Sobron, Bayu, Rani, \& Meidawati, 2019) pembelajaran daring dapat difahami sebagai pendidikan formal yang 
diselenggarakan oleh sekolah yang peserta didik dan guru berada di lokasi yang berbeda sehingga memerlukan sistem telekomunikasi interaktif untuk menghugungkan keduanya dan berbagai sumber saya yang diperlukan didalamnya. Jadi pembelajaran daring merupakan pembelajaran yang dilakukan oleh seorang pendidik kepada peserta didik yang tidak dibatasi dengan jarak dan waktu dengan menggunakan perangkat internet sebagai penghugungnya.

Pada hakikatnya pembelajaran daring merupakan pembelajaran yang lebih menekankan pada penggunaan model Student Centred dalm pembelajaran (Masni, 2020), dengan demikian maka pembelajaran daring selain dapat memutus mata rantai penyebaran covid-19 tetapi juga dapat membiasakaan peserta didik untuk belajar mandiri (Puspitasari \& Noor, 2020). Pembelajaran daring pada dasarnya bukanlah sebuah model pembelajaran yang baru karena jauh sebelum adanya pandemi covid-19 masyarakat telah mengenal istilah pembelajaran jarak jauh (PJJ), namun istilah tersebut kini disebut dengan pembelajaran daring. Pembelajaran daring ini kemudian menjadi tren baru dalam dinamika pembelajaran di masa pandemi covid-19 (Muhaimin, 2020). Fakta tentang pembelajaran daring tidak semudah yang dibayangkan dan dipaparkan dalam teori-teori pembelajaran dan hasil-hasil penelitian karena disamping harus meningkatkan sumberdaya dalam pelaksanaan pembelajaran daring juga harus mempersiapkan dari segi fasilitasnya.

\section{Dinamika Lembaga pendidikan dalam Pengelolaan Pembelajaran Daring}

Pembelajaran daring bukanlah hal yang baru dikenal dan digunakan dalam proses belajar mengajar. Konsep pembelajaran daring sudah ada sejak munculnya begrbagai istilah dalam pembelajaran yaitu e-book, e-learning, e-library, dan e-education. Namun dalam kenyataannya tidak semua lembaga pendidikan apalagi pendidikan dasar mau dan mampu menggunakannya dalam proses belajar mengajar. Bahkan sangat sedikit dari lembaga pendidikan baik itu pendidikan tinggi, pendidikan menengah, apalagi pendidikan dasar. Pada umumnya pembelajaran daring mulai digunakan di dunia khususnya Indonesia sejak bulan Maret tahun 2020. Pembelajaran daring digunakan bersamaan dengan datangnya pandemi covid-19. Pengelolaan pembelajaran merupakan upaya mengatur proses pembelajaran yang didasari pada konsep dan prinsip pembelajaran untuk tercapainya tujuan pembelajaran yang efektif dan efisien dengan menentukan perencanaan, strategi dalam pelaksanaannya, dan evaluasi pada akhir pembelajaran (Erwinsyah, 2017).

Lembaga pendidikan dasar harus menerima kenyataan yang ada. Dengan adanya pandemi covid-19 maka pembelajaran yang selama ini dilakukan dengan bertatap muka harus beralih kepada pembelajaran dalam jaringan (daring). Ini merupakan suatu model pembelajaran yang relatif baru, apalagi jika diterapkan di lembaga pendidikan dasar yang mana peserta didiknya masih perlu pengawasan dan bimbingan dalam proses pembelajaran. Jika melihat dari kemanfaatan dan proses pembelajaran daring maka akan dijumpai bahwa pembelajaran daring lebih mengedepankan pembelajaran mandiri yang mana peserta didik menjadi pusat belajar. Masalahnya kemudian adalahh peserta didik pada tingkat dasar cenderung belum mampu untuk belajar secara mandiri maka perlu dampingan orang tua dalam proses pembelajaran daring.

Banyak permasalahan yang dijumpai dalam penerapan pembelajaran daring ini, mulai dari ketersediaan infrastruktur seperti listrik dan internet. Belum lagi permasalahan ketrbatasan dana dari masyarakat untuk memiliki komputer, tablet, dan android. Permasalahan-permasalahan yang dihadapi dalam pembelajaran daring saat ini bukan saja sebatas pada infrastruktur saja namun permasalahan peserta didik, guru, atau bahkan lembaga pendidikannya namun melibatkan elemen lain yaitu jaringan internet, fasilitas, dan peran orang tua. Jika merujuk pada data dapodik kemendikbud pada tahun 2020 sebagaimana diungkapkan pohan dalam bukunya, maka didapatkan data statistik lembaga pendidikan dasar dan menengah yang belum memiliki akses internet sebanyak 46.272. jika dipersentasikan menjadi $18 \%$. Terdapat juga 8.281 lembaga pendidikan yang belum tersambung listrik (Pohan, 2020). 
Dari data diatas maka dibutuhkan pengelolaan yang baik dari sebuah lembaga pendidikan dasar untuk dapat melaksanakan pembelajaran daring di masa pandemi ini dengan begitu banyaknya dinamika yang dihadapai. Pengelolaan lebih populer disebut dengan istilah manajemen, dan diantara fungsi manajemen antara lain merencanakan, mengorganisasikan, mengarahkan, dan mengawasi atau mengevaluasi (Mubarok, 2020). Dalam pengelolaan pembelajaran daring dibutuhkan komponen pendukung dalam pembelajaran sehingga proses pembelajaran daring dapat berjalan dengan efektif. Beberapa unsur komponen pendukung yang bisa dijalankan dalam pembelajaran daring antara lain: memilih kompetensi yang sesuai dengan keadaan pandemi, memperhatikan indikator evaluasi yang sesuai untuk mencapai kompetensi, mengembangkan sistem pembelajaran yang mudah, serat menentukan evaluasi dan penilaian yang disesuaikan dengan kondisi pandemi covid-19 (Madjid, 2014).

\section{Menyusun Rencana Pembelajaran Daring \\ Perencanaan pembelajaran menurut}

Kaufman dalam Harjanto menyebutkan istilah perencanaan merupakan suatu hal yang diperlukan dalam rangka mencapai tujuan yang absah dan bernilai (Harjanto, 2013). Selanjutnya William H. Newman dalam (Madjid, 2014) berpendapat bahwa perencanaan adalah proses penentuan apa yang harus dilakukan. dengan demikian perencanaan mengandung rangkaian keputusan, kebijakan, program, metode, dan prosedur dalam menentukan sebuah kegiatan. Perencanaan pembelajaran yang dimaksud disini adalah perencanaan pembelajaran yang disusun sebelum pembelajaran dilaksanakan dengan menentukan materi, metode, media, dan estemasi waktu.

Langkah-langkah yang dapat dilakukan dalam perencanaan pembelajaran antara lain merumuskan tujuan, pengalaman belajarar, kegiatan belajar mengajar, keterlibatan pihak terkait, bahan dan alat pembelajaran, rencana evaluasi dan pengembangan selanjutnya (Sanjaya, 2015) Adapun komponen dalam rencana pembelajaran paling tidak memiliki tujuan, materi, metode, sumber, dan pemnilaian (Farida, 2012).

Lembaga pendidikan dasar perlu menyusun program rencana pembelajaran yang sesuai dengan kondisi yang dihadapi dengan kata lain menyesuaikan dengan pandemi covid-19. Dimana pembelajaran harus dilakukan dengan menerapak Soscial Distancing. Tentu rencana pembelajaran yang selama ini direncanakan dalam kondisi normal akan sangat jauh berbeda dengan rencana pembelajaran dimasa pandemi covid-19. Banyak hal yang harus dipertimbangkan oleh lembaga pendidikan dasar dalam merencanakan pembelajaran yang sesuai dengan standar protool kesehatan, mulai dari materi pembelajaran, tugas dan latihan, metode yang akan digunakan, media pembelajaran, sampai pada pendampingan dalam pembelajaran daring mengingat jenjang pendidikan dasar masih membutuhkan pendampingan dalam penggunaan media pembelajaran daring dan belajar mandiri peserta didik.

2. Melakukan Pemetaan dalam Pembelajan Daring

Istilah pemetaan ini merupakan istilah yang digunakan penulis, jika dibawa kepada manajemen maka pemetaan disini yang dimaksud adalah pengorganisasian. Lembaga pendidikan dasar harus memetakan apa yang telah direncanakan dalam perencanaan pembelajaran. Menurut Farida Rahim dalam pembelajaran hal yang harus dipenuhi dalam pemetaan tersebut antara lain: Kompetensinya, indikatornya, materinya, medianya, metodenya, waktunya, evaluasinya (Rahim, 2012).

Memetakan materi pembelajaran, memetakan metode pembelajaran, memetakan media pembelajaran, memetakan tugas dan latihan soal, sampai pada pemetaan peserta didik yang mempunyai orangtua yang super sibuk, dan peserta didik yang kurang mampu dalam bidang ekonomi dan IT. Dalam memetakan pembelajaran juga perlu dilakukan pemetaan kemampuan siswa, pemetaan alat dan media yang tersedia, memetakan langkahlangak dan skenario pembelajaran, memetakan waktu pembelajaran, memetakan fasilitas pembelajaran. 
Perlunya pemetaan tersebut tujuannya adalah untuk memudahkan pendidik, peserta didik, dan orang tua dalam pembelajaran daring karena pembelajaran daring tidak hanya membutuhkan biaya yang mahal namun dibutuhkan kecakapan pihak terkait untuk mengoperasikan media yang digunakan dalam pembelajaran daring. Dalam hal pemetaan media yang digunakan, dalam pembelajaran daring harus dipetakan kapan penggunaan dan pemilihan aplikasi pembelajajaran daring. Demikian juga dalam pemetaan waktu pembelajaran supaya waktu pembelajaran juga dapat dipetakan tidak selama pembelajaran luring.

\section{Pelaksanakan Pembelajaran Daring}

Pelaksanaan pembelajaran daring harus dilakukan sesuai dengan perencanaan yang telah disusun kemudian komitmen dengan pemetaan yang telah ditetapkan. Ini penting untuk dilakukan dalam pelaksanaan pembelajaran daring untuk dapat mencapai tujuan pembelajaran. Pelaksanaan pembelajaran daring di masa pandemi dilakukan dalam bentuk pembelajaran yang menggunakan aplikasi sebagai sebagai medianya, dan aplikasi yang dapat digunakan antara lain zoom, google class room, dan whatsApp group (Engko \& Usmany, 2020). Pelaksanaan pembelajaran daring harus dilakukan dengan memperhatikan segala aspek pendukungnya untuk mencapai tingka keefektifan pembelajaran.

Efek positif dari pembelajaran daring ini memungkinkan pembelajaran dilakukan ditempat masing-masing tanpa harus bertemu langsung untuk menghindari penyebaran covid-19. Memungkinakan pembelajaran dilakukan diwaktu yang berbeda sesuai dengan kondisi yang memungkinkan untuk melakukan pembelajaran, dan memberikan efek belajar mandiri bagi peserta didik (Sadikin \& Hamidah, 2020). Dampak pandemi covid-19 dalam pembelajaran yang lain yaitu perubahan cara belajar, meningkatnya kemampuan dalam menggunakan teknologi dalam pembelajaran, dan meningkatnya kemandirian peserta didik dalam belajar (Firman \& Rahayu, 2020).

Dengan demikian maka pembelajaran daring di lembaga pendidikan dasar akan berjalan dengan efektif dan efisien apabila didukung dengan aspek-aspek yang lain mulai dari perencanaa, pemetaan, dan sarana dan prasarana yang memadai. Dalam pelaksanaan pembelajaran daring maka dapat dilaksanakan dengan membuat grup whatsApps, membuat google class room, menggunakan zoom meeting. Dengan aplikasi tersebut maka whatsApp digunakan untuk mengirim voice note pertanyaan, penjelasan, atau praktik membaca dalam pembelajaran. Kemudian google class room dapat digunakan untuk pelaksanaan latihan maupun quiz, ujian tengah semester dan ujian akhir semester, sementara aplikasi zoom dapat digunakan untuk pertemuan pertama untuk menjelaskan rencanan pembelajaran, dan silabus dan bahkan digunakan pada saat pertemuan terakhir dalam pembelajaran. Hal tersebut dilakukan dengan mempertimbangkan keadaan ekonomi peserta didik, dan pertimbanganpertimbangan lainnya.

Melakukan metode pembelajaran yang bervariatif, dengan pembelajaran daring maka metode yang digunakan tidak hanya menggunakan metode ceramah namun menggunakan metode penugasan, latihan soal, diskusi kelompok. Dalam proses pembelajaran daring dibutuhkan komunikasi yang baik antara lembaga pendidikan dasar, guru, siswa dan oragn tua. Tanpa komunikasi yang baik maka proses pelaksanaan pembelajaran daring tidak akan berjalan sebagaimana mestinya. Dalam pelaksanaan pembelajaran daring seharusnya tercapainya pertemuan yang maksimal karena tidak membutuhkan waktu dan jarak untuk dapt mengikuti proses pembelajaran. Dalam pembelajaran daring orang tua tidak harus mengantarkan anakanaknya ke sekolah.

Pengelolaan pembelajaran daring hendaknya memenuhi dan memperhatikan aspek-aspek diantaranya :

Memperhatikan tujuan pembelajaran : Lembaga pendidikan dasar hendaknya memperhatikan tujuan pembelajaran dalam pelaksanaan pembelajaran daring. Jjika mengacu pada kurikulum, maka kurikulum dalam pembelajaran daring tidaklah sama dengan kurikulum yang biasanya berlaku ketika pembelajaran dilakukan dengan luring. Akan sangat berbeda antara kurikulum sebelum pandemi dengan kurikulum setelah 
adanya pandemi. Pemerintah kemudian menetapkan apa yang disebut dengan kurikulum darurat. Dalam hal ini pemerintah tidak serta merta memerintahkan lembaga pendidikan dasar untuk menggunakan kurikulum darurat, namun ada opsi-opsi tertentu yang ditawarkan oleh pemerintah mengenai kurikulum tersebut, diantaranya : memberikan kebebsan kepada lembaga pendidikan dasar untuk menggunakan kurikulum yang ada yaitu kurikulum pendidikan nasional, menyarankan untuk menggunakan kurikulum darurat yang mana dalam kurikulum darurat terdapat penyederhanaan dalam kompetensi dasar pada mata pelajaran tertentu, dan yang paling terakhir yaitu memberikan kebebasan kepada lembaga pendidikan dasar untuk menyederhanakan kurikulumnya secara mandiri mengingat kondisi dan situasi di suatu daerah berbeda-beda sehingga tidak memungkinkan penyamaan satandar kompetensi dan standar kurikulum.

Menyusun Skala prioritas : ini menjadi sangat penting untuk dilakukan oleh lembaga pendidikan dasar mengingat banyak item-item tertentu yang tidak mungkin dilakukan dalam pembelajaran daring atau tidak mungkin dilakukan disaat pandemi covid-19. Disinilah kemudian pentingnya pemetaan skala prioritas untuk dilakukan di lembaga pendidikan dasar. Dalam menyusun skala prioritas tersebut maka lembaga pendidikan dasar perlu menyusun jadwal pembelajaran sebagai bentuk pengorganisasian dalam pembelajaran. Ketika jadwal kegiatan dan jadwal pembelajaran telah disusun maka akan mudah untuk untuk mendahulukan skala prioritas yang telah ditentukan. Perlunya penyusunan skala prioritas apabila dikaitkan dengan proses pembelajaran maka akan memudahkan orang tua untuk mengarahkan anak-anaknya dirumah untuk belajar.

Begitu juga dengan kebiatan-kegiatan lain dalam lembaga pendidikan dasar akan dapat berjalan dengan efektif dan efisien dengan menggunakan susunan skala prioritas tersebut. Pada masa pandemi seperti sekarang ini maka yang menjadi skala prioritasnya adalah bagaimana pembelajaran tersebut bisa berjalan dengan baik dan materi pembelajaran bisa difahami oleh peserta didik dengan menggunakan aplikasi pembelajaran daring. Tentunya dengan menyederhanakan standar kompetensi dalam pembelajaran. Demikian juga dalam hal pendanaan, lembaga pendidikan dasar harus merasionalisasikan anggarannya untuk dapat melakukan kegiatan-kegiatan yang kiranya dapat dilakukan pada saat pandemi dan melihat kembali rencana awal untuk menentukan skala prioritasnya.

Tegas dan Aktif dalam bersikap : Ini menjadi penting karena pada saat yang sama dalam pembelajaran daring seorang tenaga pendidik tidak akan mampu secara penuh untuk mengontrol peserta didiknya dalam pembelajaran. Demikian juga dalam hal pengerjaan tugas, maka tenaga pendidik harus lebih aktif dan intens untuk berkomunikasi dengan wali murid untuk mengkomunikasikan proses pembelajaran dan pengerjaan tugas sehingga tetap kondusif. Setelah tenaga pendidik aktif dalam berkomunikasi serta membimbing peserta didik dalam pembeajaran maka tenaga pendidik harus bersikap tegas dalam menegakkan aturan dalam pembelajaran daring. Tegas supaya peserta didik tetap ikut dalam pembelajaran dan tegas terhadap tugastugas yang telah diberikan kepada peserta didik. Ketika tenaga pendidik sudah bersikap tegas dan aktif dalam pembelajaran maka tidak akan ada peserta didik yang terlambat mengumpulkan tugas.

Mengontrol dan memaksimalkan waktu : ini merupakan hal yang sangat penting dalam pembelajaran daring. Seorang pendidik harus melakukan komunikasi yang intens dengan wali murid untuk ikut serta dalam mengontrol belajar anak. Seorang pendidik harus memastikan kepada orang tua siswa untuk mengarahkan anak-anak untuk belajar mandiri sebelum proses belajar mengajr dilakukan, hal ini dilakukan untuk memudahkan pemahaman siswa dan dapat mengefisienkan waktu mengingat akan banyaknya kendala yang mengintai dalam pembelajaran daring. Permasalahn yang dimaksud adalah jeleknya koneksi internet, habisnya kuota internet, mati listrik, dan downnya aplikasi maupun perangkat pembelajarannya.

Saat pembelajaran daring tidak ada terjadi tatap muka antara guru dengan siswa secara lansung namun terjadi tatap muka sebatas jangkauan kamera. Jelas hal tersebut 
dapat mengurangi jangkauan pengawasan guru terhadap murid sehingga guru tidak dapat mengawasi apa yang dilakukan siswa selain menampakkan wajah di kamera dalam pembelajaran daring. Selanjtnya dalam pembelajaran daring seharusnya tenaga pendidik tidak bertele-tele dalam menyampaikan materi pembelajaran. Tenaga pendidik harus lebih pandai mengelola waktu pembelajaran sehingga waktu yang tersedia dapat dilakasanakan secara maksimal.

\section{Melakukan Evaluasi}

Dalam melakukan evaluasi komponen konteks pembelajaran daring paling tidak memiliki tiga indikator yaitu indikator tujuan, indikator kebutuhan, indikator lingkungan. Demikian juga evaluasi komponen imput dalam pembelajaran daring paling tidak memiliki empat indikator, yaitu : indikator pendidik, indikator peserta didik, indikator sarana dan prasarana, indikator perangkat pembelajaran. Sementara evaluasi komponen proses paling tidak memiliki lima indikator, yaitu : indikator proses, indikator aktivitas pendidik, indikator aktivitas siswa, indikator kendala, dan indikator solusi (Riyanda, Herlina, \& Wicaksono, 2020).

Tidak mudah memang untuk mengalihkan bentuk pembelajaran yang selama ini melekat pada lembaga pendidikan dasar, pendidik, peserta didik, dan orang tua peserta didik. Tentunya dalam pelaksanaan pembelajaran daring terdapat banyak problem, tantangan dan rintangan. Oleh karena itu dibutuhkan evaluasi. Lembaga pendidikan dasar harus mengadakan evaluasi pembelajaran daring yang selama ini sudah berjalan. Dengan melakukan evaluasi maka sebuah lembaga pendidikan dasar akan dapat mengetahui apa yang menjadi problem dalam pembelajaran daring. Dengan demikian maka lembaga pendidikan dasar akan mampu mencarikan solusi terhadap problem yang terjadi.

Kaitannya dengan komponen maka evaluasi indikator tujuan menjadi hal yang sangat penting untuk dilakukan, apakah tujuan yang telah disusun dan direncanakan tercapai atau tidak dalam proses pembelajaran daring. Indikator kebutuhan juga demikian, lembaga pendidikan dasar harus memenuhi apa yang menjadi kebutuhan guru dan siswa dalam proses pembelajaran daring. Dan terakhir Indikator lingkungan, ini bisa dilakukan dengan melakukan kolaborasi dengan orang tua siswa untuk menciptakan suasana lingkungan belajar yang kondusif dan menyenangkan. Apabila lingkungan tidak sesuai dengan minat peserta didik maka ini dapat menjadi faktor menurunnya motivasi anak untuk mengikuti proses pembelajaran dengan baik.

Demikian juga dalam evaluasi komponen imput dalam pembelajaran daring harus memperhatikan indikator pendidik, apakah pendidiknya monoton dalam pembelajaran, atau pendidiknya tidak sesuai kualifikasi akademiknya, atau bahkan pendidiknya tidak mempu mengoperasikan teknologi secara baik. Penting juga mengevaluasi indikator peserta didik, karena peserta didik menjadi komponen yang krusial dalam proses pembelajaran daring. Peserta didik harus di evaluasi baik menggunakan evaluasi harian, mingguan, bulanan dan bahkan evaluasi setiap semesternya. Indikator sarana dan prasarana, juga tidak kalah penting untuk dievaluasi, ketersediaan komputer, kuota internet, lingkungan mengajar yang kondusip dan indikator perangkat pembelajaran ini yang dalam hemat penulis tidak mungkin luput dari evaluasi karena dalam perangkat pembelajaran tersebut akan tertera rencana pembelajaran, metode yang digunakan, alokasi waktu pembelajaran dan program semester maupun program tahunan. Sementara evaluasi komponen proses paling tidak memiliki lima indikator, yaitu : indikator proses, indikator aktivitas pendidik, indikator aktivitas siswa, indikator kendala, dan indikator solusi

\section{CONCLUSION}

Kesimpulan dari tulisan ini antara lain bahwa lembaga pendidikan dasar merupakan lembaga yang menjadi awal mula pendidikan formal seorang anak untuk dapat melanjutkan pendidikan kejenjang yang lebih tinggi yaitu lembaga pendidikan menengah pertama, menengah atas, dan lembaga pendidikan perguruan tinggi. Syarat untuk bisa masuk ke lembaga pendidikan dasar yaitu berumur tujuh tahun. Sementara pembelajaran daring singkatan dari dalam jaringan artinya proses belajar mengajar daring bisa dilakukan dengan 
menggunakan jaringan internet. Pembelajaran model daring ini memungkinkan pendidik dan peserta didik melakukan pembelajaran tanpa harus bertemu. Pengelolaan pembelajaran daring di lembaga pendidikan dasar tidaklah semudah yang dibayangkan. Banyak hal yang harus dipersiapkan oleh lembaga pendidikan dasar untuk dapat beradaptasi dengan model pembelajaran daring, mulai dari kompetensi tenaga pendidiknya, perangkat pembelajarannya yang berbeda dengan pembelajaran luring, sarana dan prasarananya serta komunikasi dengan peserat didik dan orang tuanya. Kaitannya dengan pengelolaan maka pengelolaan sangat erat kaitannya dengan manajemen. Lembaga pendidikan dasar dapat mengelola pembelajaran daring dengan menyusun rencana dan tujuan pembelajaran, melakukan pemetaan sakala prioritas, melaksanakan pembelajaran daring sesuai dengan waktu dan rencana pembelajaran, dan melakukan evaluasi yang meliputi evaluasi konteks pembelajarannya, evaluasi komponen proses, dan evaluasi komponen imputnya.

\section{REFERENCES}

Efferi, A. (2015). Dinamika Persaingan Antar Lembaga Pendidikan. Acta Universitatis Agriculturae et Silviculturae Mendelianae Brunensis, 53(9), 16891699. Retrieved from http://publications.lib.chalmers.se/record s/fulltext/245180/245180.pdf\%0Ahttps:// hdl.handle.net/20.500.12380/245180\%0 Ahttp://dx.doi.org/10.1016/j.jsames.2011 $.03 .003 \% 0$ Ahttps://doi.org/10.1016/j.gr.2 017.08.001\%0Ahttp://dx.doi.org/10.1016 /j.precamres.2014.12

Engko, C., \& Usmany, P. (2020). Dampak Pandemi Covid-19 Terhadap Proses Pembelajaran Online. Jurnal Akuntansi, 6(1), 23-38.

Erwinsyah, A. (2017). Manajemen kelas dalam meningkatkan efektifitas proses belajar mengajar. TADBIR: Jurnal Manajemen Pendidikan Islam, 5(2), 87-105.

Farida, R. (2012). Pengajaran Membaca di Sekolah Dasar, Jakarta: PT. Jakarta: PT. Bumi Aksara.

Firman, F., \& Rahayu, S. (2020). Pembelajaran online di tengah pandemi covid-19. Indonesian Journal of Educational Science (IJES), 2(2), 81-89.

Gunawan, I. (2013). Metode penelitian kualitatif. Jakarta: Bumi AKsara.

Harahap, A. W., \& Hamidah, D. (2019). Optimalisasi Peran Guru Dalam Proses Pembelajaran. Jurnal Serunai Administrasi Pendidikan, 8(1). Harjanto. (2013). Perencanaan Pengajaran. Jakarta: PT. Rineka Cipta.

Isman, M. (2016). Pembelajaran Moda Dalam Jaringan (Moda Daring). Sumatra Utara: Muhammadiyah University Press.

Lakoriha, R. P., Wowor, H. F., Elektro, T., Sam, U., \& Manado, R. (2018). Pengembangan Sistem Pengelolahan Pembelajaran Daring Untuk Sekolah Menengah Kejuruan. Jurnal Teknik Informatika, 13(4), 1-6. https://doi.org/10.35793/jti.13.4.2018.28 106

Madjid, A. (2014). Perencanaan Pembelajaran. Bandung: PT. Remaja Rosda Karya.

Masni, N. M. (2020). Pembelajaran Daring Sebagai Upaya Study From Home (SFH) Selama Pandemi Covid 19. Cetta: Jurnal Ilmu Pendidikan, 3(3i).

Mubarok, R. (2020). Model Pengelolaan Praktik Pengalaman Lapangan pada Masa Pandemi. Kelola: Journal of Islamic Education Management, 5(2), 147-160.

Muhaimin, R. M. (2020). Upgrade Kompetensi Guru PAI Dalam Merespon Pembelajaran Jarak Jauh Dimasa Pandemi Covid-19. AL-FIKR: Jurnal Pendidikan Islam, 6(2), 75-82.

Pandoman, A. (2020). Analisis Quietus Politik Terhadap Upaya Pemerintah Menangani Wabah Covid-19 Pasca Deklarasi Public Health Emergency Of International Concern (PHEIC). Ulumuddin: Jurnal Ilmu-Ilmu Keislaman, 10(1), 1-12.

Pohan, A. E. (2020). Konsep pembelajaran daring berbasis pendekatan ilmiah. Purwodadi-Grobogan: Penerbit CV. SARNU UNTUNG.

Pratama, R. E., \& Mulyati, S. (2020). Pembelajaran Daring dan Luring pada Masa Pandemi Covid-19. Gagasan 
Pendidikan Indonesia, 1(2), 49-59. https://doi.org/10.30870/gpi.v1i2.9405

Presiden, R. (2003). Undang-undang Republik Indonesia nomor 20 tahun 2003 tentang sistem pendidikan nasional. Departemen Pendidikan Nasional.

Priyatno, A. (2020). Pendidikan Islam dalam Turbulensi Era 4.0. Al-Fikr: Jurnal Pendidikan Islam, 6(1), 1-9.

Puspitasari, A., \& Noor, T. R. (2020). Optimalisasi Manajemen Pembelajaran Daring dalam Meningkatkan Adversity Quotient (AQ) Siswa Selama Pandemi Covid-19. Jurnal Elkatarie: Jurnal Ilmu Pendidikan Dan Sosial, 3(2), 439-458.

Raco, J. (2018). Metode penelitian kualitatif: jenis, karakteristik dan keunggulannya. Jakarta: PT. Grasindo.

Rahim, F. (2012). Pembelajaran Membaca di Sekolah Dasar. Jakarta: Bumi Aksara.

Rahman, K. (2018). Perkembangan Lembaga Pendidikan Islam di Indonesia.

Tarbiyatuna, 2(1), 1-14. Retrieved from https://www.jstage.jst.go.jp/article/amr/1 /5/1_010501/_article/-

char/ja/\%0Ahttp:/www.ghbook.ir/index. فر هنى و رسانه هاى =

نوين\&option=com_dbook\&task=readonli ne\&book_id $=136 \overline{5} 0$ \&page $=73 \&$ chkhash $\mathrm{k}=$ ED9C9491B4\&Itemid=218\&lang=fa $\& \mathrm{tmpl}=\mathrm{component} \% 0 \mathrm{Ahttp}: / / \mathrm{dx}$.

Riyanda, A. R., Herlina, K., \& Wicaksono, B. A. (2020). Evaluasi Implementasi Sistem Pembelajaran Daring Fakultas Keguruan dan Ilmu Pendidikan Universitas Lampung. Jurnal IKRA-ITH Humaniora, 4(1), 66-71. Retrieved from https://journals.upiyai.ac.id/index.php/ikraithhumaniora/article/view/669

Sadikin, A., \& Hamidah, A. (2020). Pembelajaran Daring di Tengah Wabah Covid-19:(Online Learning in the Middle of the Covid-19 Pandemic). Biodik, 6(2), 214-224.

Sanjaya, W. (2015). Perencanaan dan desain sistem pembelajaran. Jakarta: Kencana Prenadamedia Group.

Sobron, A. N., Bayu, B., Rani, R., \& Meidawati, M. (2019). Pengaruh Daring Learning terhadap Hasil Belajar IPA Siswa Sekolah Dasar. Seminar Nasional
Sains \& Entrepreneurship, 1(1).

Subhan, A. (2012). Lembaga pendidikan Islam Indonesia: abad ke-20. Kencana.

Surur, A. M., \& Nadhirin, A. U. (2020). Manajemen Waktu Pembelajaran Daring Di Masa Pandemi Covid-19 Pada TK Dharma Wanita 1 Baleturi. As-Sibyan: Jurnal Pendidikan Anak Usia Dini, 5(2), 81-94. Retrieved from http://jurnal.uinbanten.ac.id/index.php/as sibyan/article/view/2939

Syarif, J. (2015). Dinamika Lembaga Pendidikan Ma'arif NU dalam Sistem Pendidikan nasional. Banjarmasin: Antasari Press. 